\title{
The Leading Traits of the Modern Corporate Leader: Comparing Survey Results from 2008 and 2018
}

\author{
Robert Karaszewski $^{1}$ (D) and Rafał Drewniak ${ }^{2, *}$ \\ 1 College of Business Administration, American University in the Emirates, \\ Dubai 503000, United Arab Emirates; robkara@umk.pl \\ 2 Department of Organizational Innovation Management, Faculty of Management, Bydgoszcz University of \\ Science and Technology, 85-790 Bydgoszcz, Poland \\ * Correspondence: rafal.drewniak@pbs.edu.pl
}

Citation: Karaszewski, R.; Drewniak R. The Leading Traits of the Modern Corporate Leader: Comparing Survey Results from 2008 and 2018. Energies 2021, 14, 7926. https://doi.org/ $10.3390 /$ en 14237926

Academic Editor: Sergey Zhironkin

Received: 19 October 2021

Accepted: 24 November 2021

Published: 26 November 2021

Publisher's Note: MDPI stays neutral with regard to jurisdictional claims in published maps and institutional affiliations.

Copyright: (c) 2021 by the authors. Licensee MDPI, Basel, Switzerland. This article is an open access article distributed under the terms and conditions of the Creative Commons Attribution (CC BY) license (https:/ / creativecommons.org/licenses/by/ $4.0 /)$.

\begin{abstract}
This article deals with the evolution of leadership in the corporate business environment by presenting the results of comparative empirical studies conducted in 2008 and 2018. Based on an analysis of empirical research on the 2000 largest global corporations, obtained from the Forbes Global 2000, this work presents the changes that took place over a decade in the characteristics and competencies of contemporary leaders. The results allowed us to identify the desired characteristics, competencies, and character traits of contemporary leaders. In fact, the comparative analysis of these data showed the dynamics of change in the approach of global corporate leaders over the decade. The research results have important implications for the energy sector. Some of the companies participating in the study operate in the energy sector, therefore the opinions of these CEOs indicate significant determinants of modern leadership in this type of enterprise. When analysing the research results on the vision and scope of leadership impact in corporate business, we pointed, among other things, to the assessment of leadership traits, the evolution of leadership activities' delegation, and the assessment of the importance of managers' individual action areas and leadership factors.
\end{abstract}

Keywords: leadership; leading traits; leadership styles; leadership evolution; energy sector; corporate policy and strategy

\section{Introduction}

Nowadays, when companies are in constant pursuit of more and more ambitious goals with rapid technological advancements and high expectations of specialist employees, the role of the leader in building the social potential of a company is paramount. As a matter of fact, leadership is a combination of specific character traits and talents that allow a manager to induce others to act as expected. It is a type of social influence in which one person can impact the behaviour of another person in order to stimulate effective action [1]. It is the art of mobilising others to act. A leadership style is essential for employee commitment [2] and, consequently, for the development and success of the organisation as a whole [3]. When we consider the factors determining the success or failure of modern enterprises and institutions, or even social structures, the particular importance of the leaders of these organisations should be emphasised. Indeed, the responsibility for the results achieved lies precisely with the leaders to a significant extent. When analysing the way employees act, one can express an accurate opinion on the character, hierarchy of values, and principles promoted by those responsible for creating the vision and organisational culture of the top management [4]. With all certainty, the personality, qualifications, and values of an organisation's leaders influence the current actions and long-term attitudes of employees [5].

The issue of leadership discussed in the present study is interesting also due to its holistic character. It is a subject that attracts economists, political scientists, sociologists, psychologists, and philosophers. In recent years, the interest of researchers and management 
theoreticians in the sphere of leadership and the factors that determine its effective application has grown steadily [6]. One of the matters highlighted in this respect is the importance of a broad spectrum of factors such as positive leadership [7,8]. Positive organisational scholarship enjoys such interest because it points to the immense success, above-average results, or high efficiency achieved by some organisations, as well as the strategies and tactics applied to achieve this goal. Executive conduct must be constantly adapted to the requirements of specific situations [2,9] (pp. 111-116). This approach implies that leadership should have two dimensions-directive and supportive. This is due to the fact that the skills and motivation of employees change over time; therefore, the composition of directive and supportive elements in leadership actions must be adjusted to each specific situation on an ongoing basis, and the effectiveness of the executive's actions depends directly on how accurately this composition is chosen. Numerous studies on leadership and extensive literature on the subject have contributed to a deeper understanding of this phenomenon and its impact on the success of an organisation. There are review studies, largely based on a systematic literature review methodology [7,10-14], tackling specific issues related to the importance of modern leaders' characteristics and the effectiveness of leadership styles.

Empirical studies carried out thus far are still an insufficient contribution to the understanding of leadership practices and their outcomes in shaping intra-organisational relationships, as well as the effectiveness of particular tools aimed to impact the team. Although this knowledge is well-established, this classification is particularly relevant to factors affecting the range of tools used and management style. Our in-depth analysis of the literature on the subject [15-19] found only a few papers that actually broadened the knowledge base about the specific features of leadership in corporate business conditions. There is a clear need to deepen the analysis with respect to the pace of change in leaders traits, the implemented vision, and the scope of influence of global business leaders. In an era of intense transformation in the global environment of modern corporations, there is a surprising lack of publications on changes in leadership traits and the effectiveness of the tools used. Thus, there is a need for more in-depth research into the development of corporate leadership traits, the applied vision, communication, and leadership impact areas $[7,12,20]$. Such research would significantly broaden the current knowledge base. A similar cognitive gap exists on how leadership evolution affects outcomes, such as the level of intra-organisational relationships, the organisational involvement of employees, and their welfare $[11,13,14,21]$. It is also unclear to what extent identified leadership attributes are relevant in specific contexts. Research so far has highlighted the importance of numerous attributes associated with entrepreneurial leadership, such as vision, knowledge transfer, effective communication, risk-taking, and creativity [22], but has shown a lack of consensus and coherence on the theoretical and conceptual basis for the evolution and development prospects of corporate leadership $[10,12,23]$.

In the course of the empirical research, we conceptualised the issue by analysing selected items from the literature in the field of leadership. However, the outcomes are largely dispersed, and there is no uniform framework for issues related to different areas of organisational leadership, raised at the individual, team, organisational, and social levels of analysis. This article attempts to partially fill this gap by pointing out the essence and importance of leadership in shaping and stimulating effective actions through analysing the dynamics of change and the evolution of leadership traits over one decade.

\section{The Notion of Leadership: Theoretical Background}

Leadership has long been a subject of intensive interest, and sometimes even fascination. A new leader is usually associated with an expectation of fundamental changes in the organisation and in particular the solutions to its problems. At the same time, management potential is severely limited by its organisational context: structure, power relations, environmental conditions, etc. Leadership should therefore be examined in its contemporary context: its behaviours in organisational change, and processes such as creating a vision for 
the future or getting employees involved in change. This paradigm is part of the "transformational era" of leadership development [24-26]. The representatives of this trend initially stressed the importance of building a vision and delegating powers, which would enable subordinates to be fully involved in the achievement of the organisation's objectives [26-28]. This was based on the fact that organisations, while contemplating their future, focus their attention on employees, their relationships, behaviours, building organisational culture, etc. This trend can also be observed among theoreticians, as confirmed by publications in the world literature $[7,14,29]$. Currently, this is being complemented through defining ways of engaging with building positive expectations. Without a doubt, leadership is a complex process that involves relational, situational, and behavioural aspects [30,31].

There are a plethora of definitions dealing with the concept of leadership that have evolved over recent decades [32-34]. One of the most compelling definitions quotes Bass ([35], pp. 11-21), drawing attention to the perspective of the leader's personality. Thus approached, leadership is a combination of specific character traits and talents that allow a leader to induce others to act as expected. The strength of interpersonal relationships and the ties between the leader and the members of a group also play a key role here. These ties are built on the basis of the personality traits of the leader [5,14,36] (pp. 171-176). Leadership is most often defined as influencing the behaviour of others [37]. It is a type of social influence in which an executive can impact the behaviour of another person in order to stimulate effective action. As such, it is the art of mobilising another to act, creating new patterns of behaviour, and providing guidance on modifying and changing the intensity of certain behaviours [38]. P.G. Northouse [15] points to four key leadership traits:

- Leadership is a process;

- Impact is necessary for leadership to exist;

- Leadership occurs only in a group context;

- Leadership is conditioned by the achievement of goals.

In turn, a leader's task is to create conditions that stimulate team effectiveness. Other researchers [39] stress that leadership aims to achieve results through the actions of others, so it is essential to create coherent and goal-oriented teams. As it follows, it can be assumed that effective leaders are those who build teams that can deliver results by leveraging all possible situations.

On the one hand, leadership can therefore be defined as the process by which a person seeks to influence a group to achieve common goals. On the other hand, it is seen from the perspective of 'trait leadership' [36,40]. Thus, the process approach is not based on the individual characteristics or skills of the leader, but rather on the very essence of activity that takes place between the leader/manager and their subordinates. In this sense, leadership activities are mainly aimed at coordinating and directing the group's own work through hierarchical dependencies, building a specific structure of relations, and showing interest in the lives of team members [5]. Leadership is therefore about relations between people who vary in terms of power. Others point out that it is a process of creating a sense and essence of collaboration, which is essential for understanding the purposefulness of action. On the contrary, the character approach links leadership to the team leader's special traits and skills or specific talents (mainly innate) that make them a group leader [16,20,35,36,41-43] (pp. 4-8).

According to Deming, a leader must be aware of the fact that it is necessary to create conditions stimulating the development of creativity in employees. This way, they will be able to reveal their skills and propose innovative changes for the company. Leadership is therefore in line with total quality management (TQM), as there are close links between leadership effectiveness and the implementation of the TQM guidelines [44]. Analysing the essence and meaning of leadership in the context of positive organisational scholarship focuses on the development of organisations and their members through positive aspects and managerial actions that are above-average and inspiring $[7,8,17,45,46]$. When analysing the concept of positive leadership in the context of global business, Youssef and Luthans ([42], p. 541) define it as 'the systematic and integrated manifestation of leadership traits, 
processes, intentional behaviours and performance outcomes that are elevating, exceptional and affirmatory of the strengths, capabilities and developmental potential of leaders, their followers and their organisations over time and across cultures'.

This approach is completely at odds with that of classical management, since leadership is an antithesis of the vision of management proclaimed by its creators. There are several reasons for this. The first is the inseparable connection of the analysed concept with the human behind it, whose role was marginalised by F.W. Taylor, H. Ford, K. Adamiecki, H. Gantt, and many of their contemporaries. However, the concepts inextricably linked with leadership were almost 'repulsive' to the precursors of management science, and the prioritised 'machine' could not have leadership traits. Intuition, self-awareness, self-control, instinct, or emotion were perceived as non-quantifiable and thus difficult to understand and accept by those whose education and experience was rather technical and lacking in knowledge about the complexity of human nature. Even today, it is often difficult for a person with a strong engineering and technical orientation to explain the role of, for instance, social intelligence in building effective instruments to inspire subordinates. Classical definitions of management emphasize decision-making that is based on measurable and verified data. This inevitably eliminated the possibility of using leadership instruments.

While leadership can be seen as one of the most studied topics, it remains one of the more elusive phenomena of our time $[32,47,48]$. To precisely define leadership is an extremely complex and multi-faceted task. Stogdill ([49], p. 7), referring to years of research, stated that the number of definitions of the concept is similar to the number of researchers, scientists, and practitioners who have tried to explain it. Over the past 50 years, at least 65 systems for classifying leadership dimensions have been developed [33,50]. One of the more interesting proposals is that of Bass [35], who noted that leadership is seen as the focus of group processes. This means that the leader becomes the main driving force behind the group's activities and changes, which is a direct result of the will of the team led. He saw a tendency to conceptualise leadership on the basis of a personality perspective that suggests that leadership is a combination of specific character traits and abilities that allow a leader to induce others to perform specific actions. They included enthusiasm, drive for leadership, honesty and integrity, self-confidence, cognitive ability, and knowledge on the subject of management $[14,35,40]$.

The analysed notion can also be defined as actions or behaviours of a leader aimed at introducing changes in a given group [35,51,52]. Looking at the problem from a different perspective, one can see that the discussed term also involves the specific strength of relations and human ties between the leader and their followers [1,19]. In this approach, the prevailing issue is the power of influence and the way in which this power is wielded, resulting in a change in the behaviour of subordinates. Top management can also be equated with actions to support individual members of the group in pursuit of given objectives and expectations. A leader is not always convinced that they have the right arguments or that they can present them in a reasonable way; in other words, they believe that something needs to be done, but may have difficulties in communicating that feeling. Moreover, participation in the decision-making process is very time-consuming and does not always have to be equally accepted by all subordinates. Moreover, employees may be reluctant to take the actions that they judge are the responsibility of the leader, so the process of influencing subordinates may not result in the intended actions. Therefore, the professional satisfaction and success of employees in most cases depend on leadership styles $([14,26,52,53]$ (p. 535).

Another level on which the concept of leadership is defined points to the behaviour and actions of the leader. In this sense, Fiedler [54] believes that leadership behaviour, in general, includes all activities that involve the leader in directing and coordinating the work of subordinates. This includes structuring relations, appreciating or criticising, and showing interest in ethics and in the feelings of team members [40]. Another perspective in which this concept can be presented is the strength of relationships. Here, leadership is considered to be the relationships between members of a group that is diverse in terms 
of power. Bass [35] also points out the narrow view that leadership is an instrument for achieving objectives and is often defined in the context of the division of roles and the initiation of structures. On the contrary: the perspective of leader characteristics does not fully reflect the leader's essence thus it should be expanded to include a wide range of the attributes expected or required by co-workers $[2,8,53]$. This approach to leadership describes the leader as a person supporting their subordinates and indicating the directions that will lead to the achievement of the set goals.

To be effective, a leader must have specific character traits and an adequate level of knowledge and skills [55,56] (pp. 61-86). In-depth literature studies, including an analysis of numerous publications on leadership qualities, show that researchers focus their efforts primarily on the moment a leader emerges and on assessing the effectiveness of their leadership. The evolution of the trait theory of leadership indicates that the key lies with the constant development of the leader, and the effectiveness of their actions depends on their flexibility and adaptability. Thus, the evolution of leadership traits and their expression indicates that these two things are interdependent, and it is only when both are assessed that the effectiveness of the leader can be determined ([57], pp. 1095-1119).

Among the various views on the nature of leadership, there is an approach that shows that a leader should first and foremost have the gift of predicting the direction of an organisation's development and that people should be willing to follow this $[8,19]$. Thus, the proponents of this approach argue that the fact of having a vision and tuning team members to it is outdated because it treats adaptive situations as if they were technical situations. Indeed, adaptive situations are not susceptible to top-down solutions and are difficult to define and resolve because of employee commitment and the need for all employees to take responsibility. Leading is a permanent process and cannot be the duty of a small group of people during an isolated event. Since everyone in the business world is facing adaptive challenges, leadership should be seen as a learning strategy. In such a situation, the manager must be able to mobilise people to face challenges by adapting their values, changing their point of view, and teaching them new habits. For an authoritarian person who prides themselves on their ability to combat difficult problems, such a change is usually a sudden awakening.

In other words, leadership is the art of making people want to take action to realise common aspirations. This also applies to building employee commitment, creating opportunities for presenting new ideas, and appreciating employees, which helps to stimulate their innovation. This also includes the involvement of employees in decision-making, enabling them to define their own work, the well-being of employees, the collection and management of new ideas, the promotion of innovation among employees, and the creation of conditions for sharing knowledge and ideas [58]. Although some people have innate character traits that predispose them to lead, most people live in a practical business reality in which their leadership skills must be deliberately shaped to achieve maximum potential leadership outcomes [47]. Gandolfi and Stone [32] highlight the need for five components of leadership:

- $\quad$ There must be one or more leaders;

- Leadership must have followers;

- It must be targeted at a legitimate action;

- An appropriate course of action must be adopted;

- Objectives and targets must be defined.

At the same time, it should be stressed that one of the key aspects of modern leadership is the ability to strengthen employees' involvement in achieving the objectives of the entire organisation $[14,33]$. Stimulating employee innovation through involvement requires creating opportunities to submit ideas, and also to implement them, and for employees to be appreciated. Other conditions include the inclusion of employees in decision-making, enabling them to define their own work, the well-being of employees, the collection and management of new ideas, the promotion of innovation among employees, and the creation of conditions for sharing knowledge and ideas [52,58]. Broad interest in leadership issues 
also includes the analysis and characterisation of factors affecting the level of employee commitment and the measurement of the same. In this context, a leader should ensure that employees can independently make use of the resources allocated to them, which in turn determines the innovativeness of their actions. Employees committed to their work identify themselves with the company, look for challenges, aim to realise their professional ambitions, fulfil their duties, think innovatively, and take actions that will serve to improve the competitiveness of the entire organisation. Experiencing such a professional life should be internally rewarding $[5,51]$.

\section{Methodology}

In the empirical part, we addressed the problem of leadership in the specific conditions of the corporate environment by presenting the results of comparative empirical studies conducted in 2008 and 2018. This analysis made it possible to identify the desired attributes, competencies, and character traits of contemporary leaders. The comparative analysis of these data allowed us to indicate the directions of changes in the approach taken by global corporation leaders over a decade. The study is therefore a valuable characterisation of a wide range of issues related to leadership traits. It is also worth noting that, in both years, the presented results were obtained using the same research instrument, while the research sample consisted of the same corporations. This helped obtain data and information, the analysis of which allowed us to prepare a unique and-despite a diligent analysis of the available literature on the subject-unprecedented study of this type.

The conceptualisation of this research project began with the thorough literature analysis outlined above, highlighting the scientific projects on the topic. The first task was to determine the scope of the study. Although it was assumed that it would cover the largest corporations in the world, a specific list and sample size had to be chosen. After reviewing the available materials, one of the most cross-sectional lists proved to be the 2006 Forbes Global 2000 list of the world's largest corporations. In view of the need to subject the adopted research methodology to the widest possible consultation, and in particular to verify the main research tool, the questionnaire, we decided to conduct a pilot study and discuss the assumptions of the research instrument with the leaders of selected organisations before undertaking the main study. The main study was therefore preceded by a pilot study, in which the leaders of friendly organisations referred to the assumptions of the research instrument. The survey questionnaire was also consulted by experts from the Japanese Union of Scientists and Engineers (JUSE).

The main study was conducted in the years 2006-2007 and consisted of two stages. In the first stage, questionnaires were mailed directly to the CEOs of the 2000 largest Forbes Global 2000 corporations in the world. Two months after letters were sent, reminders were mailed to corporations that had failed to answer and they were given the opportunity to participate in an online survey (using the same research instrument in electronic form). It should be emphasised here that, in both cases, questionnaires translated into both English and Japanese were used. In total, we harvested 222 participants (plus 68 returns, resulting from circumstances such as the letter not reaching the addressee, liquidation or takeover of the enterprise, or a change of headquarters). In addition, 44 corporations refused to take part in the study because of the excessive responsibilities of their CEOs or the specific corporation's internal policy prohibiting participation in scientific research. The survey return rate in 2008 was $11.1 \%$, while in 2018 it was possible to achieve a slightly higher rate of $13.2 \%$ (264 returns). This entitles the conclusion that the results can be a valuable source of information expanding the knowledge about the specificity of leadership in corporate business. It is also worth emphasizing that in both cases (in 2008 and 2018) the presented results were obtained with the use of the same research instrument, and the research group consisted of the same corporations. The developed research instrument included questions about the vision and the scope of influence of leadership in corporate business, including the characteristics of a leader, the evolution of delegating leadership activities, effective communication, and an assessment of the importance of areas of activity and leadership 
factors of the management staff. The respondents also assessed the significance level of individual leader traits using a 5-point Likert scale. This is the most popular estimation and dependency scale for measuring respondents' attitudes. All questions were closed-ended and multiple-choice. The survey questionnaire contained 15 questions and, additionally, a respondent's metric. The final version of the questionnaire and the selection of questions in the study were formulated in consultation with experts from JUSE. In fact, it ensured a high degree of accuracy of the results in terms of, inter alia, adjusting the scales and properly structuring the questionnaire.

In the second stage of the study, discussions were held directly with representatives from corporations, and experts involved in the management of leadership competence development programmes. The CEOs who left their business cards and confirmed their willingness to participate in subsequent editions of the survey were notified by e-mail. The aim was to verify the conclusions of the analysis of the data collected in the first part of the study. In order to enhance the scope of the study over time, it was conducted again in 2018 (6.4\% of questionnaires were returned). The main goal this time around was to compare the results with what transpired a decade ago, using the same research instrument and covering the same group of corporations. This allowed us to make a comparative analysis of the characteristics of leadership visions and traits over a ten-year period, tracking management evolution in this way. The results and conclusions contained in the following part of the article constitute valuable information on the scope of shaping leadership qualities in the global business environment, as well as the dynamics of their changes. The analysis of the obtained data allowed us to create a unique study, unprecedented in the available world literature.

\section{Findings}

When analysing the results, the first factor to focus on is the number of persons in the sphere of both direct and indirect influence of a leader. The direct influence of top management representatives, in most cases, extends over fewer than 50 employees-as over $62 \%$ stated in 2008 and over $69 \%$ in 2018 (Table 1). Indirectly affected by the top CEOs, on the other hand, were more than 10,000 people (as affirmed by a narrow majority in 2008, and by over $56 \%$ a decade later) (Table 2 ).

Table 1. Number of employees under a leader's direct influence as viewed by leaders of the Forbes Global 2000 world's largest corporations.

\begin{tabular}{ccc}
\hline Number of Employees Directly Influenced by a Leader & \multicolumn{2}{c}{ Corporations } \\
& $\mathbf{2 0 0 8}$ & $\begin{array}{c}\mathbf{2 0 1 8} \\
\text { Percentage of Indications }\end{array}$ \\
\hline up to 9 & $12.62 \%$ & $17.19 \%$ \\
$10-49$ & $50.00 \%$ & $52.34 \%$ \\
$50-99$ & $13.08 \%$ & $14.84 \%$ \\
$100-249$ & $9.35 \%$ & $7.03 \%$ \\
250 and above & $14.95 \%$ & $8.59 \%$ \\
\hline
\end{tabular}

Table 2. Number of employees under a leader's indirect influence as assessed by leaders of the Forbes Global 2000 world's largest corporations.

\begin{tabular}{|c|c|c|}
\hline \multirow{3}{*}{ Number of Employees Indirectly Influenced by a Leader } & \multicolumn{2}{|c|}{ Corporations } \\
\hline & 2008 & 2018 \\
\hline & \multicolumn{2}{|c|}{ Percentage of Indications } \\
\hline up to 49 & $1.83 \%$ & $0.00 \%$ \\
\hline 50-99 & $6.85 \%$ & $3.91 \%$ \\
\hline $100-249$ & $9.13 \%$ & $7.03 \%$ \\
\hline 250-999 & $8.22 \%$ & $6.25 \%$ \\
\hline 1000-9999 & $20.09 \%$ & $26.56 \%$ \\
\hline Over 10,000 & $53.88 \%$ & $56.25 \%$ \\
\hline
\end{tabular}


At present, this trend continues, although it should be noted that the number of corporate leaders who supervise fewer than 50 employees (69.54\%) has increased, while the percentage of indications for direct supervision over more than 100 people has decreased (by $8.68 \%$ compared to the study from ten years ago). This means that today's corporate leaders have direct control over smaller groups of employees. On the other hand, it should be emphasised that the number of corporations employing more than 10,000 people has increased, while the percentage of indications for corporations employing fewer than 1000 people has decreased significantly (Table 2). This trend is most evident in the case of a smaller number of employees under the indirect supervision of leaders, reaching $0 \%$ for the range of up to 49 subordinates.

\subsection{Leadership and Vision}

The conducted research also allowed us to obtain data on how the leaders of the largest corporations in the world assessed the effectiveness of methods for transferring their vision. The survey results clearly indicate that they try to use all available forms of direct contact with their subordinates. Meetings, for obvious reasons, are the most popular method-nearly $65 \%$ of respondents indicate them as the way to transfer vision (Figure 1). This form of direct contact has even gained in popularity over the last ten years, to $71.09 \%$. However, due to their specific nature, meetings do not allow leaders to reach a wider group of employees; therefore, in most cases, top management representatives use staff meetings, enabling the personnel to communicate not only the content of the objectives created but the accompanying positive emotions as well. At the same time, the fact that we live in an era of highly developed forms of communication induces the growing importance of modern forms of communication and the increasing use of methods of indirect communication, which were not prevalent ten years ago.

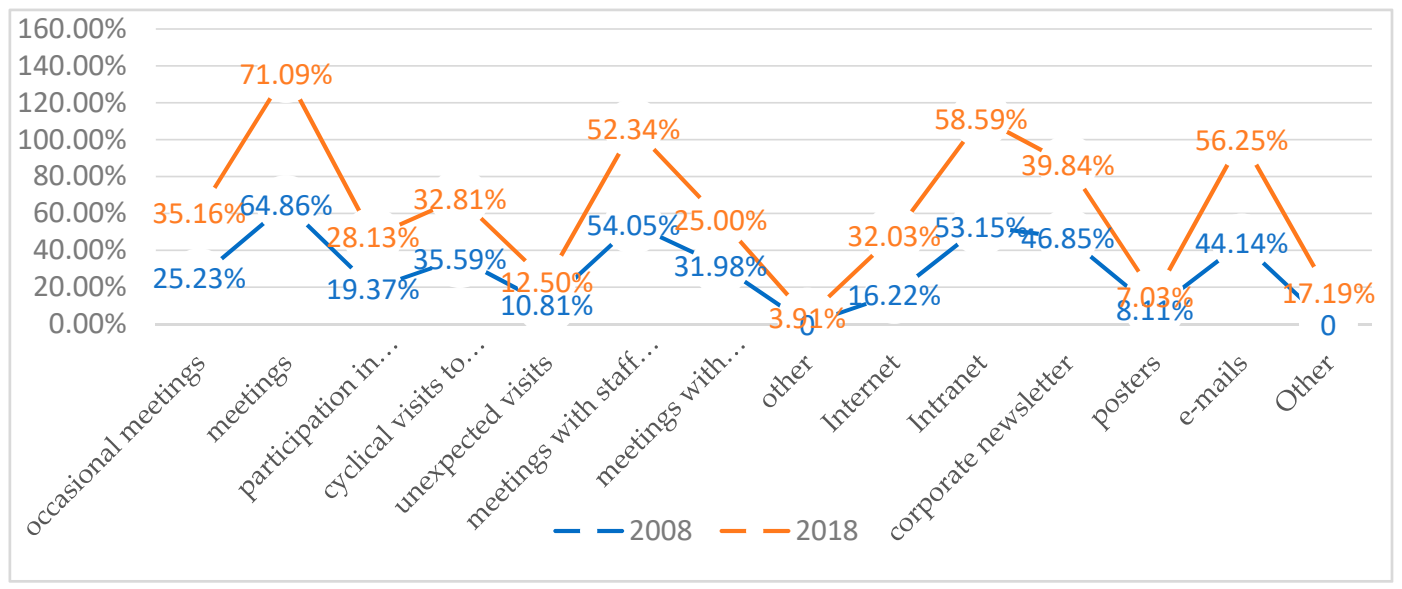

Figure 1. The effectiveness evaluation of a leader's vision-transfer methods in the opinion of leaders of the Forbes Global 2000 world's largest corporations.

It follows that indirect communication methods, such as Intranet, e-mail, or corporate newsletters, which are much less burdensome for busy corporate leaders, received much higher scores in 2018 than in the first survey, though they do not replace the key role of team and plenary meetings. Nevertheless, it is to be expected that technological developments and increasingly dynamic changes in indirect communication capabilities will contribute to the blurring of these distinctions. Still, for now, direct communication ensures a more effective absorption of important information. On the other hand, the evaluation of the effectiveness of the methods of indirect vision transfer does not show any significant differences over the ten years. 


\subsection{Cultural Diversity in Leadership}

Most of the world's largest corporations are transnational organisations, and many of them can even be considered global entities. Nevertheless, in their vision-building process, they use unified solutions that are clear to all employees or even do not take cultural diversity into account at all. Only fewer than $10 \%$ of respondents indicated that their vision is modified depending on the group to which it is addressed (Figure 2).

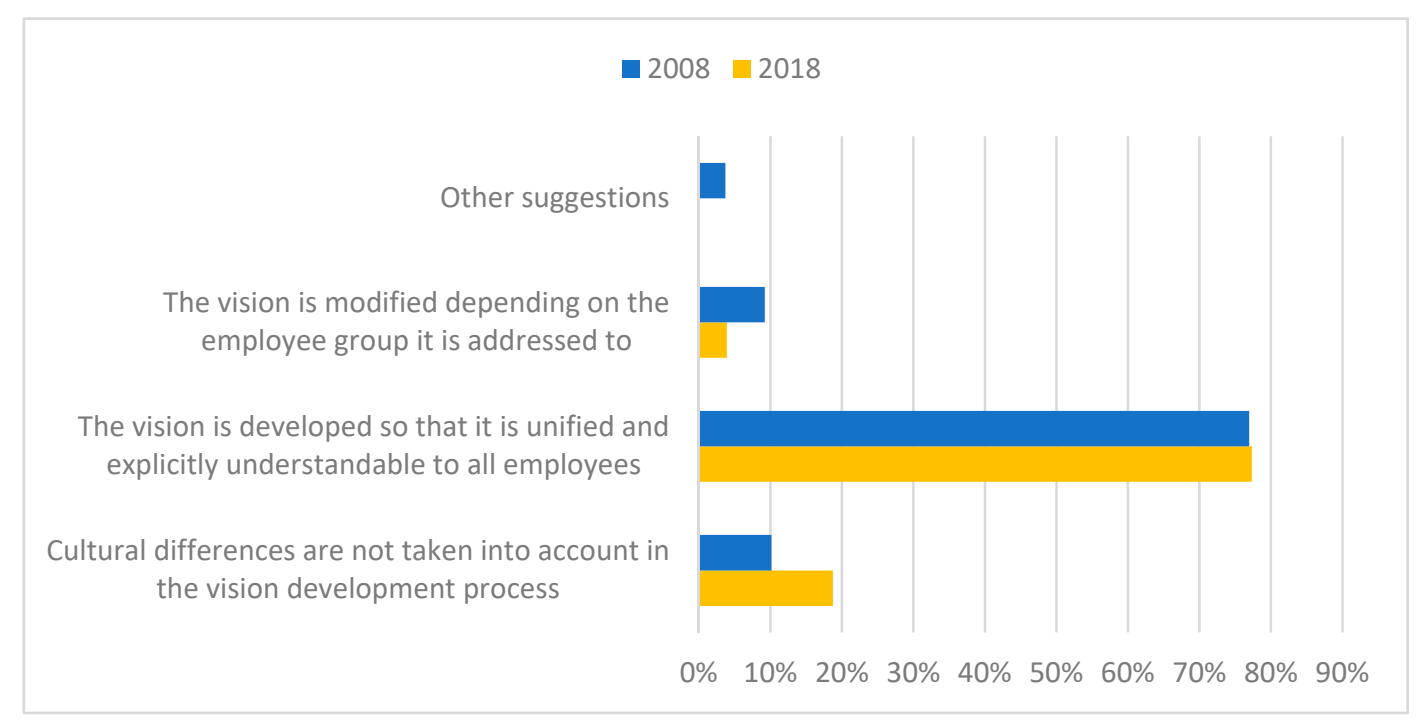

Figure 2. Impact of cultural differences on the communication of leader's vision-Forbes Global 2000 corporation leaders' assessment.

Interestingly, after ten years, the number of indications has decreased, which means that leaders have become even less concerned with the specificity of the group to which the vision is addressed. However, despite cultural diversity not being taken into account when creating a vision (an increase in indications by over $8 \%$ ), it is still understandable by all participants of the organisation (over $77 \%$ ).

Returning to the conclusions drawn from the analysis of data specific to the whole population, the tendency to create unified solutions is clearly marked here. On the one hand, this approach seems correct, as it leaves many potentially controversial and sensitive issues outside the vision, but on the other hand, there is a risk of employees' reduced willingness and ability to fully identify with the vision due to excessive unification. Incidentally, it should also be noted that corporate leaders have deeply divided opinions on the impact of corporation size on the very process of creating a vision. In 2008, more than a quarter of respondents $(27.91 \%)$ believed that the size of the organisation did not affect this issue. At the same time, $36.28 \%$ of them noticed positive aspects related to company size, whereas a similar percentage $(35.82 \%)$ of corporate representatives saw a negative or very negative impact of size on vision transference. This structure is slightly different in light of current research results. In fact, it turns out that the contemporary conditions in which companies function result in the size of an enterprise determining the process of vision creation to a greater extent. Therefore, the view that the size of the corporation does not influence the creation of a vision has lost its share for the benefit of positive and very positive influence (58.59\% of responses). At the same time, the interviewed leaders indicate that, nowadays, the size of a corporation has a negative impact on this issue to a lesser extent $(24.22 \%)$. In conclusion, the size of a business determines the process of creating its vision in a positive way more so now than it did in 2008.

The indications concerning the time horizon included in the vision and in the CEOs' actions are quite worrying. In both cases, in the opinion of most respondents, this does not exceed five years. Only fewer than $10 \%$ of the leaders believe that the vision they create exceeds one decade. This concerns both analysed sets of data; however, it should 
be noted that after ten years, corporate leaders have pointed out even more strongly that the time horizon covered by the vision is getting shorter. It turns out that, currently, only $33.59 \%$ of leaders believe that the vision does not exceed five years, while the percentage of leaders who believe that the vision they create covers no more than one year has increased significantly $(28.13 \%)$. Largely, this attitude is related to the pace of change, probably unprecedented in the history of civilisation, as well as fears about investors' perception of long-term strategies as risky futurism. The most frequently indicated vision time horizon, between six months and two years (57.04\% of indications), would seem too short, especially considering the lead time necessary to introduce breakthroughs or other innovations.

\subsection{Delegation and Leadership}

Another problem raised in the research was the issue of the delegation of leadership activities. According to the vast majority of respondents (nearly $85 \%$ ), it is possible to transfer activities included in the sphere of leadership (Figure 3). This trend has continued after a decade (currently over $90 \%$ of indications), which indicates the importance of delegating powers to lower levels in the organisational structure. This certainly helps to relieve the leader, and at the same time provides significant support for the employee motivation function. In the applied research instrument, the earlier presented suggestions of Kouzes and Posner (Posner, 2015) were used to specify individual leadership actions.

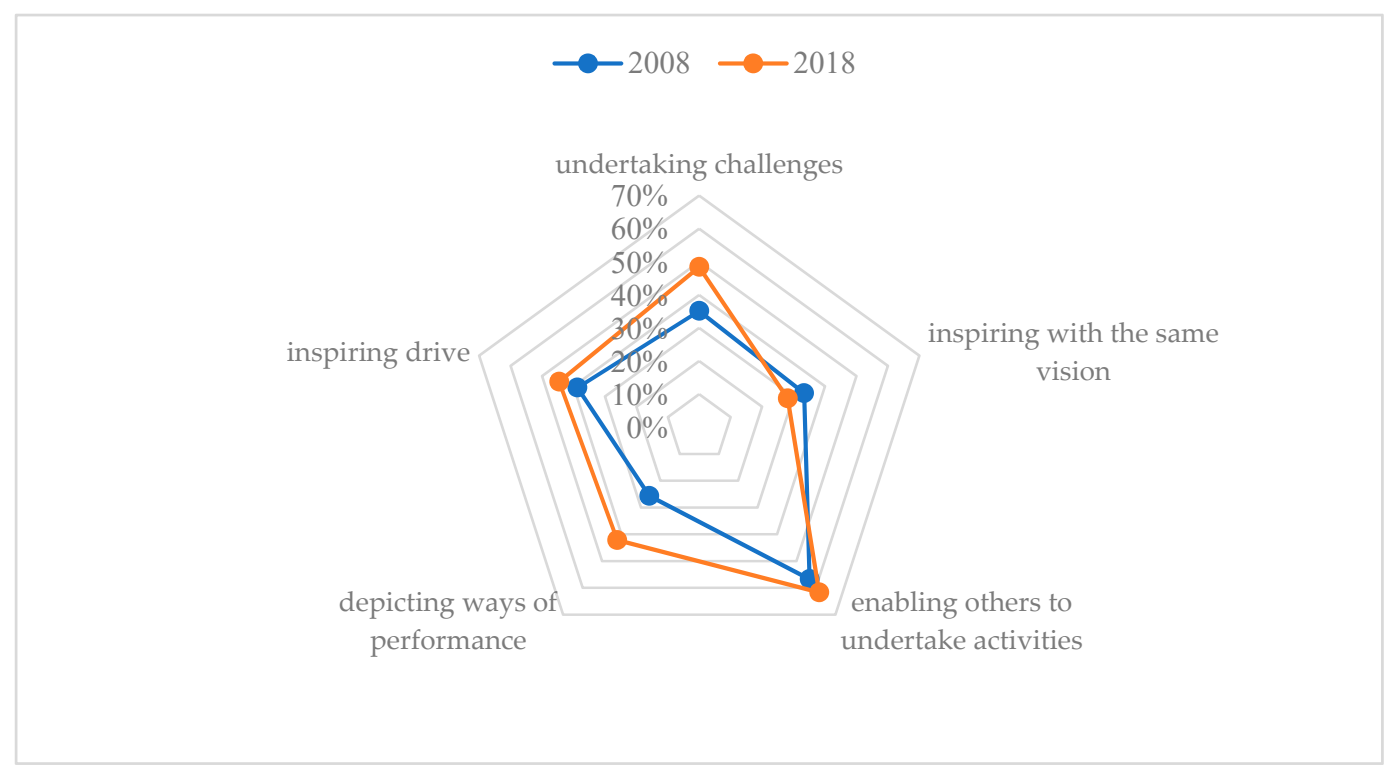

Figure 3. Evaluation of possibilities and areas in which leadership activity delegation is possible as assessed by leaders of the Forbes Global 2000 world's largest corporations.

Theoretical assumptions of leadership clearly emphasise that one of the crucial roles of a leader is to eliminate barriers and restrictions that employees may encounter. Therefore, the indications of leaders in light of the obtained results are quite puzzling. Another extremely important task of a leader is to set the rules of conduct, first and foremost by showcasing their own commitment towards the promoted ideas and values. In this case, the results obtained after ten years, in which this area has become more important (more than $42 \%$ of indications), should be greeted with satisfaction. Against the background of these indications, the opinions of the vast majority of respondents who believe that it is possible to delegate support for employees in taking action (an increase by nearly $5 \%$ ) are astonishing. Of course, a leader can-and should-use co-workers for these responsibilities, but all internal stakeholders must be absolutely certain that the leader's personal participation in these activities is their top priority.

Similar conclusions can be drawn from the analysis of answers given in relation to setting examples of conduct. It is hard to imagine how someone can set an example to other 
employees on behalf of the leader. While this proved feasible for one-third of respondents in 2008 , this percentage has decreased only slightly, and a large proportion of leaders (more than $28 \%$ ) still feel the same way. Trying to justify such a state of affairs, one may come to the conclusion that top execs try to use management tools even in areas that are the unconditional domain of leadership.

Interesting conclusions can be drawn from the comparative analysis of the results in relation to the process of creating visions. Admittedly, the vast majority of leaders are still of the opinion that the developed assumptions must fit in or be combined with the vision of top management (Figure 4).

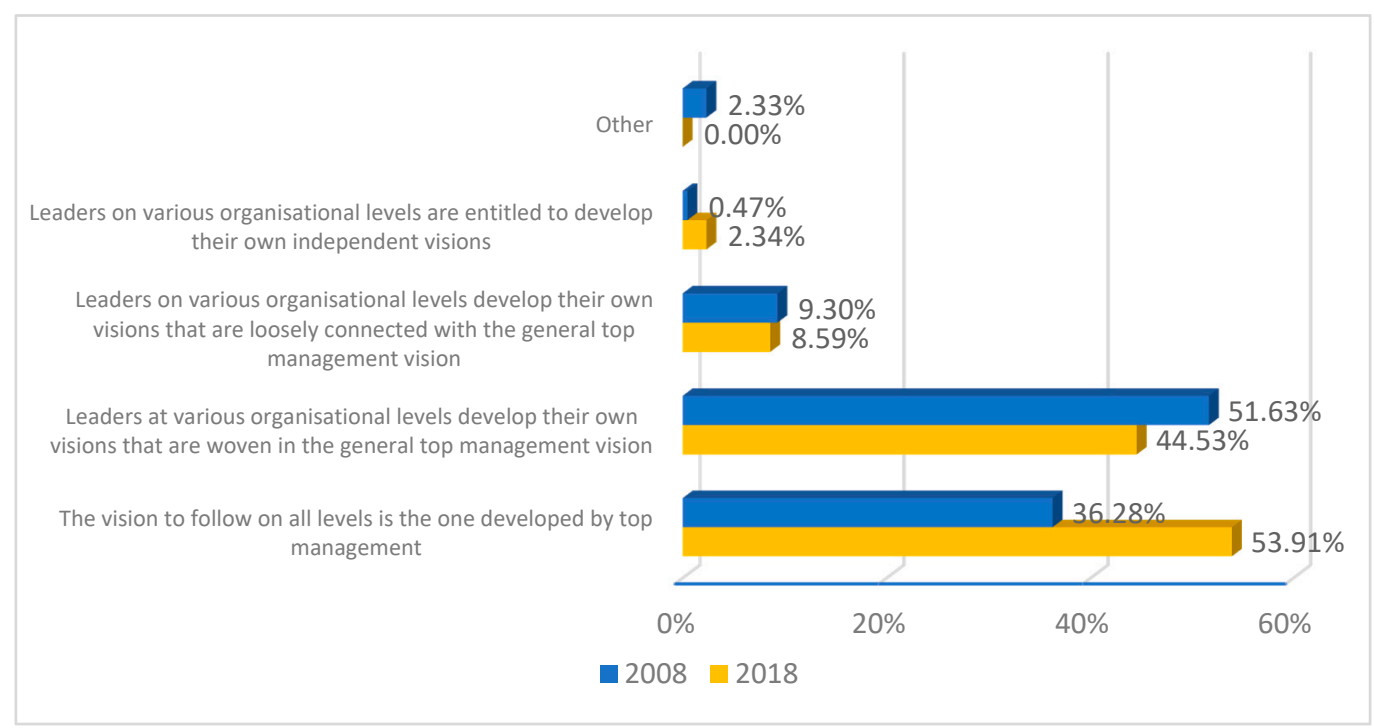

Figure 4. The vision development process as assessed by leaders of the Forbes Global 2000 world's largest corporations.

However, it should be noted that the emphasis has shifted to a more radical approach to this issue-now, more than half of those interviewed believe that the vision created by top management should apply at all levels of the organisation. At the same time, there is also a tendency for lower levels to participate in the creation of a vision or to develop it autonomously, with only a loose connection to the vision defined by top management. Such a way of perceiving the issue of creating visions on different levels of the organisation seems correct and justified in the light of theoretical assumptions.

Another intriguing issue delves into the motives that push subordinates to follow the set vision. At the very beginning of the discussion, it should be noted that in this case, too, the opinion was expressed by the leaders of corporations and not by individual employees, which may to some extent undermine their objectivity. Nevertheless, we should assume that many top CEOs are outstanding and at the same time very down-to-earth experts, and therefore able to correctly assess the motives influencing their subordinates. However, this cannot be verified without taking into account the opinions of employees. Therefore, the lack of employee perspective should be considered a shortcoming which, due to methodological conditions, we were not able to exclude.

Attention should be paid to the issue of material motivations. There is a symptomatic drop in the percentage of indications here, which shows that leaders are becoming increasingly aware that they should refute the assumption whereby an employee may act in accordance with the set vision due to their pay grade (a drop in indications by $8.53 \%$ ). This is the only variable that has recorded such a significant decrease in comparison with the other indications (Figure 5). 


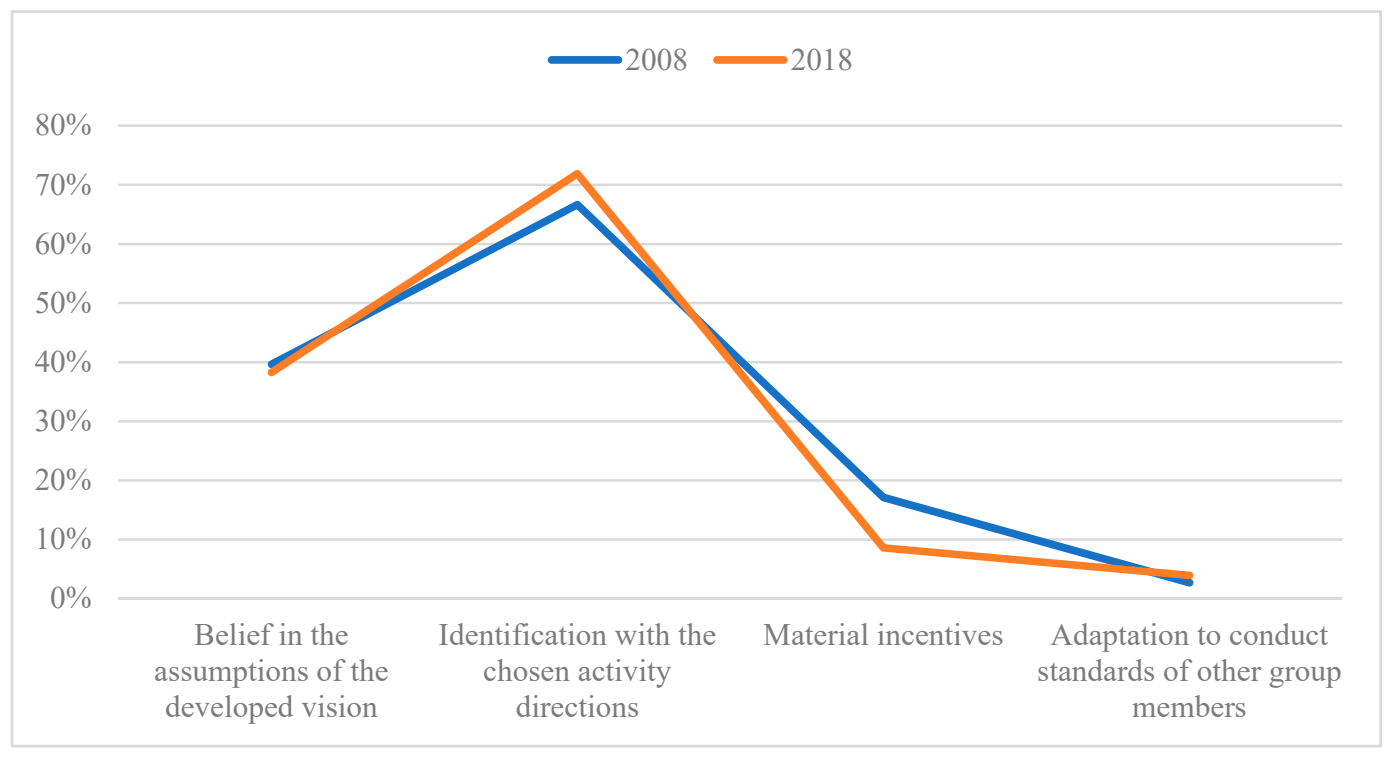

Figure 5. Motives driving subordinates to follow the developed vision as assessed by leaders of the Forbes Global 2000 world's largest corporations.

In the case of another specified stimulus, the opinions of leaders over the last decade are in complete accord: namely, about $67 \%$ of respondents in 2008 and over $71 \%$ in 2018 confirm that when subordinates identify with the activity directions set, they tend to act in line with the vision directives. Certainly, we can be pleased with the growing importance of employees identifying with the directions of corporate activities, which may evidence a positive relationship based on trust between subordinates and their superiors. On the other hand, the need to adapt to group pressure $(2.7 \%$ and $3.91 \%)$ is deemed almost irrelevant.

\subsection{Leadership Traits}

The key issue addressed in the study was to identify the most desirable leadership traits in the general context as well as in the corporate business environment. The indicated list includes not only traits, per se, but also some competencies. The main research focus was on the traits, but the will to use the indications of the ultimate authorities prevailed in this case. The category of indications included in the questionnaire was developed on the basis of the results of research conducted by Stogdill, Mann, Lord, DeVader and Alliger, Kirkpatrick and Locke, and Kouzes and Posner, among others [59-63]. The first aspect worth presenting is related to the views on corporate leadership traits and the overall vision of the leader. The juxtaposition of views on this matter presented by the surveyed top managers of corporations does not indicate that there are any major differences. This applies to both periods covered by the survey-both in 2008 and 2018, opinions on the characteristics of leaders in the corporate business environment and in general (Table 3) were similar. The group of the same characteristics of leaders was indicated, while the differences consist of the importance and place of particular traits depending on the assessed approach (general or corporate business). Thus, in the case of a general approach, the most frequent indications, rated highly, were righteousness, the ability to inspire, honesty, and responsibility (in all cases the percentage of indications was above $40 \%$ ).

In the corporate business environment, the most important features of leaders included righteousness, responsibility, foresight, and wide horizons (here, also, these features achieved above $40 \%$ of indications). At the same time, in the general context, the lowest scores were for vigilance, reliability, dominance, extroversion, maturity, task knowledge, and attentiveness (less than 10\%). It should also be noted that these characteristics have suffered the greatest decline in importance over the ten-year period. As far as the corporate business environment is concerned, the lowest scores were given to a group of similar characteristics of leaders, namely: reliability, dominance, extroversion, persistence, and 
attentiveness (these characteristics similarly received less than $10 \%$ of indications). However, the list of desirable features is very long and includes practically all of the forty-two features listed in the questionnaire.

Table 3. Evaluation of the importance level of leadership traits as assessed by leaders of the Forbes Global 2000 world's largest corporations-general context.

\begin{tabular}{|c|c|c|c|c|}
\hline \multirow{3}{*}{ Leadership Trait } & \multicolumn{4}{|c|}{ Corporations } \\
\hline & \multicolumn{2}{|l|}{2008} & \multicolumn{2}{|l|}{2018} \\
\hline & Percentage of Indications & Average Rating * & Percentage of Indications & Average Rating * \\
\hline Drive for achievements & $34.23 \%$ & 2.36 & $39.22 \%$ & 2.95 \\
\hline Adaptability & $27.03 \%$ & 2.75 & $25.49 \%$ & 2.27 \\
\hline Vigilance & $24.77 \%$ & 2.71 & $9.80 \%$ & 2.20 \\
\hline Ambition & $26.58 \%$ & 2.27 & $28.43 \%$ & 3.07 \\
\hline Wide horizons & $29.73 \%$ & 2.59 & $36.27 \%$ & 2.03 \\
\hline High competences & $46.40 \%$ & 2.32 & $25.49 \%$ & 1.96 \\
\hline Trustworthiness & $38.29 \%$ & 2.24 & $25.49 \%$ & 3.04 \\
\hline Conservatism & $22.97 \%$ & 3.33 & $10.78 \%$ & 3.27 \\
\hline Co-operation & $26.13 \%$ & 2.57 & $32.35 \%$ & 2.21 \\
\hline Courage & $28.38 \%$ & 2.22 & $22.55 \%$ & 2.17 \\
\hline Reliability & $34.68 \%$ & 2.56 & $8.82 \%$ & 2.11 \\
\hline Determination & $47.30 \%$ & 2.19 & $39.22 \%$ & 2.70 \\
\hline Dominance & $22.97 \%$ & 3.25 & $7.84 \%$ & 2.88 \\
\hline Drive for goals attainment & $31.98 \%$ & 2.38 & $29.41 \%$ & 2.67 \\
\hline Empathy & $32.43 \%$ & 2.44 & $28.43 \%$ & 2.48 \\
\hline Extroversion & $27.93 \%$ & 3.10 & $7.84 \%$ & 2.75 \\
\hline Ability to make & $34.23 \%$ & 2.59 & $21.57 \%$ & 2.73 \\
\hline Foresight & $47.30 \%$ & 2.10 & $37.25 \%$ & 2.13 \\
\hline Honesty & $40.09 \%$ & 2.31 & $42.16 \%$ & 2.28 \\
\hline Fertile imagination & $24.77 \%$ & 2.51 & $13.73 \%$ & 2.86 \\
\hline Independence & $23.87 \%$ & 2.26 & $14.71 \%$ & 1.87 \\
\hline Ability to influence others & $36.49 \%$ & 2.44 & $30.39 \%$ & 2.65 \\
\hline Showing initiative & $31.53 \%$ & 2.63 & $29.41 \%$ & 1.90 \\
\hline Having intuition & $27.03 \%$ & 2.32 & $16.67 \%$ & 2.65 \\
\hline Ability to inspire others & $41.44 \%$ & 2.71 & $46.08 \%$ & 1.96 \\
\hline Righteousness & $38.29 \%$ & 2.26 & $55.88 \%$ & 1.89 \\
\hline Intelligence & $30.63 \%$ & 2.32 & $26.47 \%$ & 3.07 \\
\hline Loyalty & $23.42 \%$ & 2.21 & $24.51 \%$ & 1.96 \\
\hline Maturity & $23.42 \%$ & 2.19 & $9.80 \%$ & 2.10 \\
\hline Motivation & $30.63 \%$ & 2.43 & $38.24 \%$ & 2.05 \\
\hline Persistence & $27.48 \%$ & 2.56 & $10.78 \%$ & 2.18 \\
\hline Developed cognitive skills & $24.77 \%$ & 2.40 & $11.76 \%$ & 2.83 \\
\hline Task knowledge & $25.33 \%$ & 2.75 & $9.80 \%$ & 2.90 \\
\hline Responsibility & $40.54 \%$ & 2.59 & $41.18 \%$ & 2.29 \\
\hline Self-awareness & $24.32 \%$ & 2.09 & $32.35 \%$ & 2.12 \\
\hline Self-confidence & $31.08 \%$ & 2.19 & $29.41 \%$ & 2.23 \\
\hline Self-control & $23.87 \%$ & 2.17 & $30.39 \%$ & 1.71 \\
\hline Sociability & $25.68 \%$ & 2.67 & $13.73 \%$ & 1.64 \\
\hline Attentiveness & $24.77 \%$ & 3.15 & $8.82 \%$ & 2.56 \\
\hline Straightforwardness & $25.68 \%$ & 2.37 & $16.67 \%$ & 3.12 \\
\hline Supporting others & $27.48 \%$ & 2.43 & $30.39 \%$ & 2.26 \\
\hline Tolerance & $24.32 \%$ & 2.41 & $23.53 \%$ & 3.46 \\
\hline
\end{tabular}

${ }^{*}$ Mean calculated on the basis of a grading scale (1-5), where 1 represents the highest grade and 5 the lowest grade.

It is worth noting that, contrary to the general context, the assessments concerning business leaders are much clearer. Interestingly, the only qualities that are considered more relevant in the general context in the latest study are courage, determination, honesty, fertile imagination, independence, ability to influence others, ability to inspire others, intelligence, loyalty, persistence, self-confidence, and supporting others. Comparing this list with the one from ten years ago, it should be emphasised that leaders in the general context are increasingly paying attention to the features that support building and maintaining relations with employees. However, the differences in ratings given to these characteristics are small. In light of the research results obtained, a corporate leader should be righteous, responsible, have foresight, perceive reality from the perspective of wide horizons, be highly motivated, and be able to inspire others. Other important features of a corporate leader should be a drive for achievements, honesty, showing initiative co-operation, selfcontrol, determination in attaining aims and empathy. Comparing the above-described set of traits to the one indicated by the interviewed leaders ten years ago, some significant changes can be observed. In the light of the research results obtained a decade ago, a corporate leader should have foresight, be determined, have high competency, a drive for 
achievements, the ability to inspire others and inspire trust, be goal-oriented, righteous, and intelligent.

Reflecting on the specificity of corporate leadership, we can note that over the last ten years, the requirements to have certain characteristics are still higher than in the general context, although their structure has changed quite considerably. In 2008, out of 42 features we distinguished, only one received a higher percentage of indications, and 12 were graded as more significant in the general context as compared to the business environment. Currently, in the general context, we can already identify 12 characteristics that have a higher percentage of indications, as many as 22 were graded as more important, and 4 of them received the same score in the general context as in the business environment. Higher importance attributed to honesty is characteristic again, although the difference in indications, in this case, was minimal in both study periods. Nevertheless, the lower importance rating given by corporate businesses to a trait as crucial as honesty is quite significant. Respondents, as it turns out, take into account the fact that operating in the corporate business environment more often than in other areas is associated with the need to make decisions that often border on unethical behaviour, but, of course, are within the limits of the law.

In conclusion, it is worthwhile to look at the pace of change concerning particular leadership traits. It turns out that the greatest decrease in the percentage of indications over the last ten years took place for (in the general context) vigilance, reliability, dominance, extroversion, maturity, developed cognitive skills, task knowledge and attentiveness, and even high competency. Conversely, less-indicated features in the corporate world included: vigilance, reliability, dominance, extroversion, persistence, and attentiveness, meaning that after ten years, views on corporate leadership attributes have indeed changed. In light of the recent study, today's corporate leaders should be righteous, responsible, and able to inspire others, as well as highly motivated and with wide horizons and foresight in their actions.

\subsection{Relationship between Top Management and Leadership}

The discussion on mutual relations between management and leadership, held in numerous publications, has led us to attempt to determine which areas of corporate management activity are the most important in the opinion of the representatives of this group. The analysis was based on Kotter's model of management and control function [64]. The indications obtained allowed us to state explicitly that the vast majority of the activities with better results are qualified by Kotter as leadership functions. In the survey conducted in 2008, the highest ranking in the entire population was achieved by 'communicating objectives' at $56.31 \%$, slightly ahead of 'creating visions' at $54.95 \%$. Notably, after a decade, both activities still lead the ranking of importance, although there have been some interesting changes at the top. At present, 'creating visions' is the most important of all activities $(56.25 \%)$ in the opinion of corporate leaders, while 'communicating objectives' decreased to $44.53 \%$ and is now third on the list by a tiny margin, after 'building teams and coalitions' at $45.31 \%$. Not far behind is 'inspiring and stimulating action' at $42.19 \%$ (Figure 6).

In two areas, the respondents increased their rating from ten years earlier: 'assigning tasks' and 'organising and engaging employees'. In fact, growth in the importance of all actions undertaken in these areas is noticeable. On the other hand, when considering the individual activities of leaders, the greatest increases in importance are for 'building teams and coalitions' (increase by $28.64 \%$ ), 'delegating powers' (increase by $12.13 \%$ ), 'generating creative solutions' (increase by $11.04 \%$ ), and 'allocating resources' (increase by $9.15 \%$ ). Conversely, the importance of four activities has decreased, and among them is 'satisfying subordinates' needs', which was already very low on the list in 2008 at 3.15\%, while after ten years it has sunk further to $2.34 \%$. The reason for such a low evaluation of an activity that is key in transformational leadership is certainly the fact that the respondents took this criterion too literally. Satisfying needs should be seen first of all as creating a platform for meeting higher-level expectations-professional development, promotion, improving 
qualifications, increasing powers, etc. It is hard to imagine that heads of corporations would consciously marginalise such a key aspect.

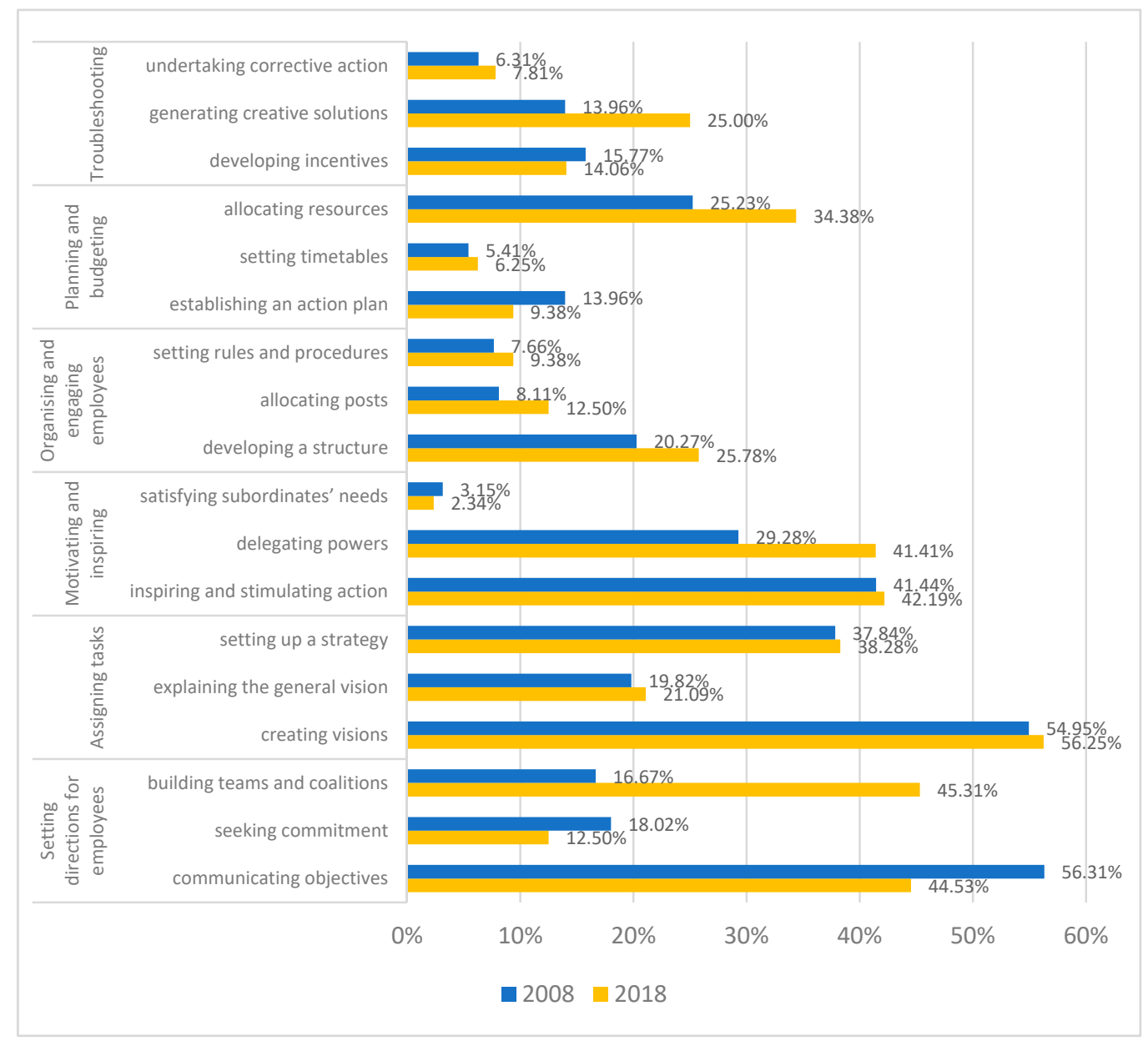

Figure 6. Evaluation of the importance of the top management activity areas by leaders of the Forbes Global 2000 world's largest corporations.

In the 2008 survey, the highest scores among managerial functions were given to "allocating resources", 25.23\%, and "developing a structure", 20.27\%. These activities are still assessed as the most important in this area, with an increase in the percentage of indications ( $34.38 \%$ and $25.78 \%$, respectively). Although they are essential aspects of the daily work of each CEO, they are only ranked seventh and eighth most important (in the 2008 survey they were ranked sixth and seventh, respectively), ahead of only four leadership activities. In general, individual activities in the area of managerial functions received quite low scores, but the leaders attributed the lowest significance to "setting timetables", 5.41\%; "undertaking corrective action", $6.31 \%$; and "setting rules and procedures", $7.66 \%$. The insignificance of these activities for corporate leaders was also confirmed by the second round of the research presented here. Although these activities have recorded a slight increase in the percentage of indications, they are still in the lowest positions, overtaking only 'satisfying subordinates' needs'. Such a distribution of answers clearly indicates that in the specific conditions of corporate business, these activities do not fall into the area of top management activities or are only a minor element thereof. It can be assumed with a great deal of certainty that when moving down the organisational structures to the level of middle and lower management, the significance of individual activities is rated very differently than by the CEOs and their deputies. 
Another problem discussed in the study concerned the significance of particular leadership factors. Respondents gave indications in the general (Figure 7a) and corporate business contexts (Figure $7 \mathrm{~b}$ ).

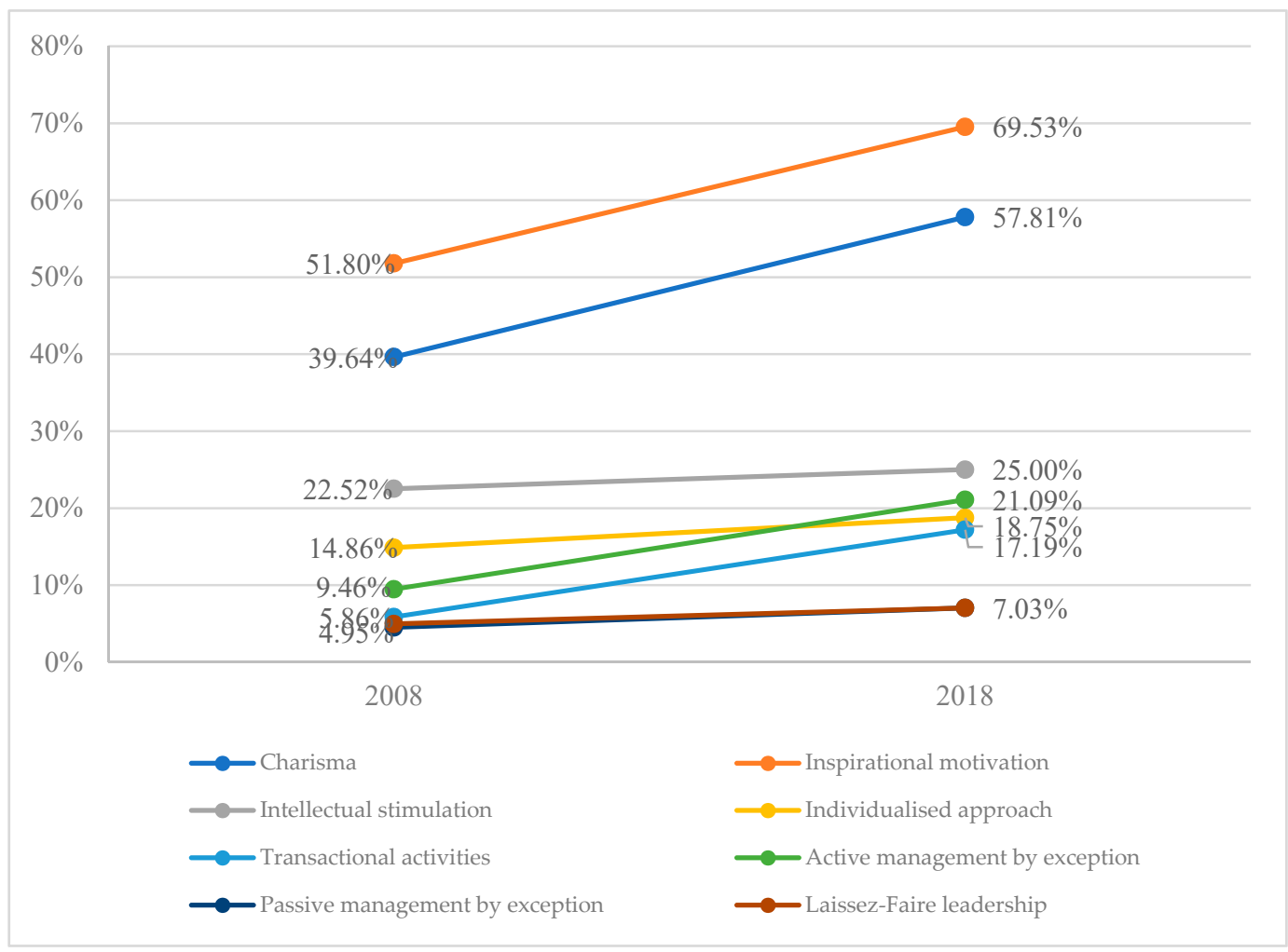

(a)

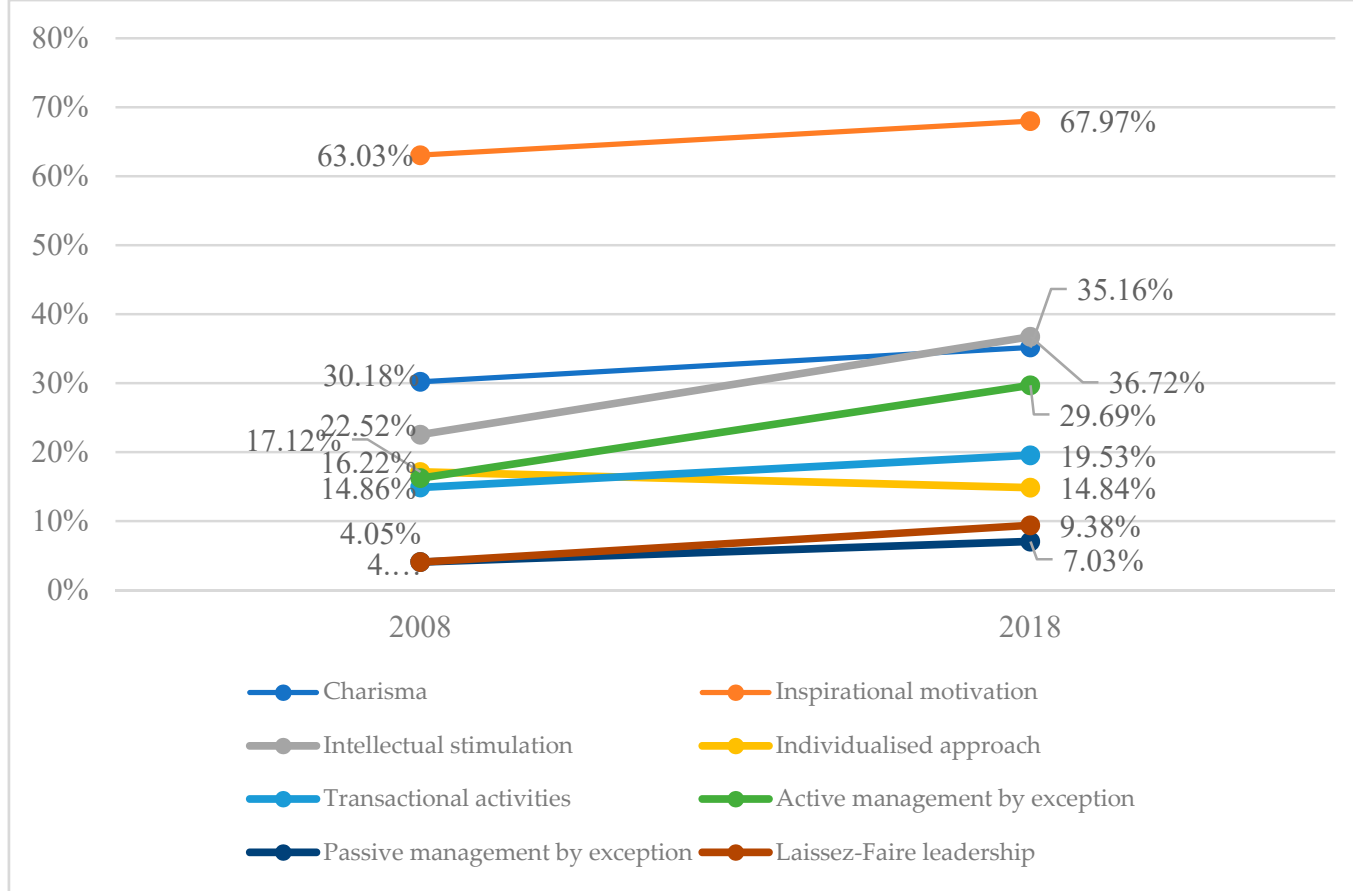

(b)

Figure 7. (a) Evaluation of the importance of leadership factors by leaders of the Forbes Global 2000 world's largest corporations-general context. (b) Evaluation of the importance of leadership factors by leaders of the Forbes Global 2000 world's largest corporations-corporate business context. 
However, this split did not reveal any major discrepancies. Minor differences were noted in the evaluation of charisma, which proved slightly more important in the general context, and inspirational motivation, which was rated as more important in the corporate business environment. Yet both charisma and inspirational motivation are key factors of leadership. In the specialised context we analysed, intellectual stimulation has been brought to the fore, while not achieving a significant increase in the percentage of indications in the general sphere, whereas a decade earlier, the factor was level in both the general and corporate business contexts.

It is also worth looking at the evaluation of the individualised approach. Overall, this factor has proven significant, with an increase in indications by nearly four per cent, while in the context of corporate business, leaders consider this factor less important compared to the rating from ten years ago. The attitude of employees towards their own role and place in the company that we presented above excludes the sense and purpose of mentoring or coaching solutions and the like. It is also worth noting that after ten years, transactional activities and active management by exception have also gained in importance. In both cases, the significance ratings have increased, and more relevance has been given to these factors in the corporate business environment, so there is a growing tendency to use transactional instruments or even a laissez-faire approach. However, such solutions should not be seen in a negative light. In many business organisations operating in a very diverse environment, invoking transactional mechanisms may not only be helpful but may even be a necessary condition for success.

\subsection{Leadership Styles and Their Dimensions}

The second issue addressed here is how leaders evaluate the effectiveness of individual leadership styles. The general (Figure 8a) and the corporate environment (Figure 8b) contexts vary substantially here over the ten-year period.

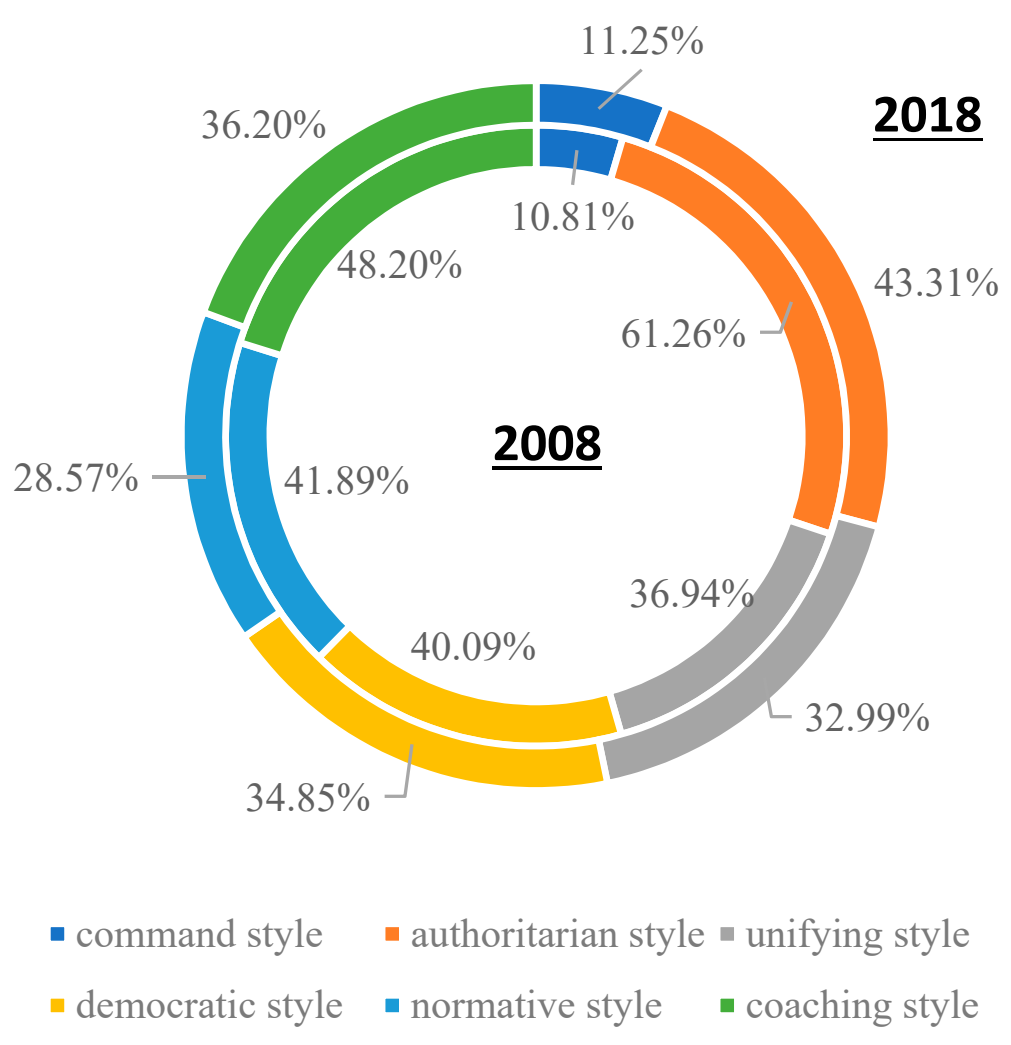

(a)

Figure 8. Cont. 


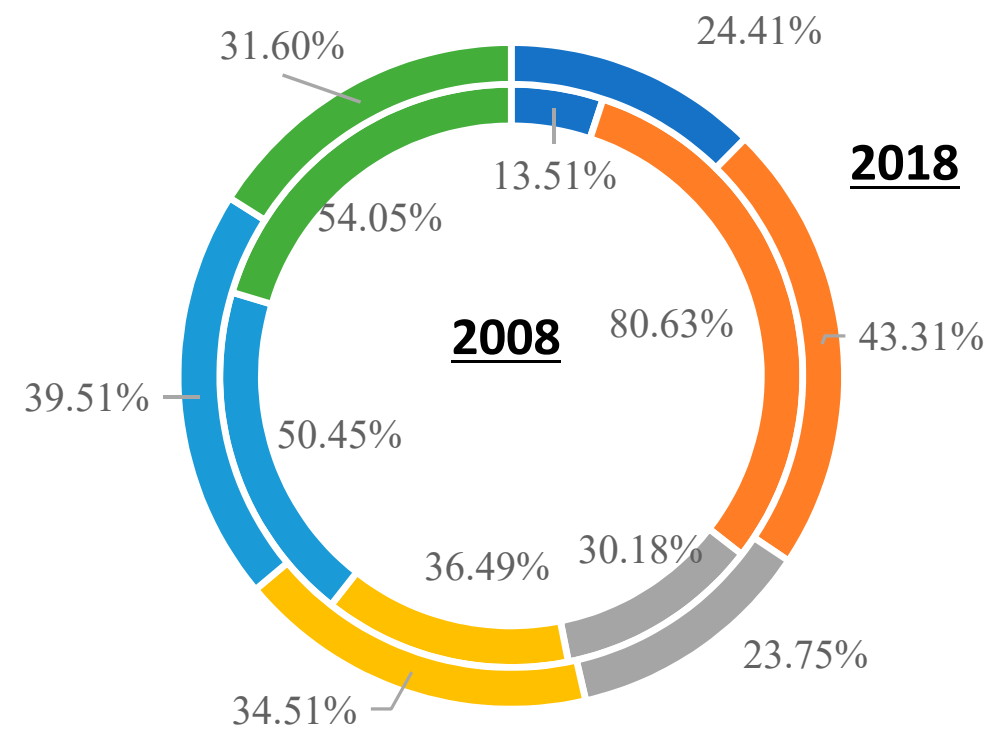

$$
\begin{aligned}
& \text { - command style } \quad \text { authoritarian style } \text { - unifying style } \\
& \text { - democratic style } \text { - normative style - coaching style }
\end{aligned}
$$

(b)

Figure 8. (a) Evaluation of the effectiveness of individual leadership styles (by D. Goleman) in the opinion of leaders of the Forbes Global 2000 world's largest corporations-general context. (b) Evaluation of the effectiveness of individual leadership styles (by D. Goleman) in the opinion of leaders of the Forbes Global 2000 world's largest corporations-corporate business context.

When analysing the results from a ten-year perspective, it should be noted that with the exception of the controversial command style, all the other assessed styles have lost their importance, both in the general context and in the corporate business environment. In light of the 2008 study, the ratings of individual styles in general conditions are slightly lower but nevertheless similar. The only exception is the unifying style, which was rated slightly higher. However, the results of the research conducted after a decade point to a greater diversity of these evaluations. The corporate business environment rates the command and normative styles higher, while the other styles were rated as more effective in the general context. Intriguing results were obtained in the case of authoritative and democratic styles. Both styles scored worse on effectiveness than ten years ago but were still at a high level. Moreover, they achieved the same scores for effectiveness (43\% in the general context and $34 \%$ for corporate business). It is difficult to unequivocally interpret such a distribution of indications. It can be seen, however, that current assessments of leadership styles are more balanced than they were ten years ago, and although the command style was rated the least effective (or one of the least effective in the corporate business environment), it was the only style that was rated higher in both cases.

\section{Discussion}

Progressing demographic changes and globalisation make it necessary to develop a platform for cooperation between people who not only represent different generations but also completely different cultures. Today's leaders need to develop the ability to reach out to people with completely different hierarchies of values and, above all, to unite them around common goals. It should be emphasised that our results and conclusions should be applied only to the research sample under study. Looking at the data, one can formulate 
observations on the impact of current changes on the future behaviour of leaders. In the area of structural change, leaders will need to fulfil new roles to focus still more on employees and teamwork. Demographic changes will necessitate the improvement of cultural diversification knowledge. Globalisation will stimulate the need to study cultural, international, and global issues. New work ethics will lead to the acceptance of different work styles and generational differences. The increase in the role of knowledge will raise the importance of training and individual work on skills improvement. Leaders will also have to take into account the use of new technologies and adapt to the transformation of power sources. A growing emphasis on increased flexibility will require improved change management. To meet all challenges, leaders of the future will need to learn about themselves and their own abilities, personality structures and mental meanderings.

As the tendency to tighten global ties between markets increases, leaders will need to understand the economic, cultural, legal, and political consequences of such actions. Future leaders will also have to learn how to manage global teams, leading them to gain a competitive advantage. Another factor that will make global thinking necessary is new technologies. Leaders who will be able to take advantage of the vast opportunities resulting from the available technological solutions, especially in the area of the use of knowledge resources located in different parts of the world, will be able to lead organisations to a sizeable competitive advantage. Another challenge concerns the value of cultural diversification, understood as leadership style and business style diversity as well as the behaviour and value-system distinctiveness characterizing individuals of different race and gender. Modern leaders are under pressure to learn not only economic and legal differences but also the social and motivational discrepancies related to working in different regions of the world. The understanding of cultural diversity must take into account both the fundamental elements and the imponderabilia that shape a specific culture, and should become a core competency of a contemporary manager.

Another issue concerns alliances between a growing number of organisations. This trend will become even more pronounced in the future. Restructuring and downsizing are leading to the emergence of a global economic environment in which the outsourcing of all tasks except key competencies can become the norm. The ability to negotiate complex alliances and manage highly intricate relationship networks will become increasingly important. The changing roles of customers, suppliers and partners also have consequences for leaders. Until now, it has been easy to distinguish between friends (customers, colleagues) and enemies (competition). In the future, however, the boundaries between them will be somewhat blurred. Therefore, building positive, long-term, and mutually beneficial relationships will become essential.

It is also worth noting that leadership may be shared in the future, as in alliances, the partners make decisions regarding what is to be done and how it is to be accomplished. The heads of corporations will no longer be the sole decision-makers. Their tasks will include creating an environment in which other leaders-who share a common vision and goals - can work together to make fruitful decisions. Unlike today's individualists, good leaders of the future will not seek control, but integration. Moreover, leaders must also learn how to create a social architecture that encourages brilliant, confident people to successfully collaborate and use their creativity. Since an individual cannot be expected to possess all the fundamental skills outlined above, and because of the demands of the very nature of an economic organisation-based on mergers, alliances, cooperation, and virtual reality-sharing leadership is likely to come to the fore as the operational model of the future.

The most important goal of meetings with specialists is not only to fulfil tasks but also to carry out a joint analysis of detected errors and to develop a plan to eliminate them. This helps to increase the level of independence and professionalism of the employees participating in the process. A system of meetings allows for the development of principles of teamwork, the easier integration of new employees, and a sense of shared responsibility for the company's results. In addition, there are two types of training in enterprises: 
compulsory (which are based on the workplace requirements) and individual (which are related to the personal career development of the employee). There is a high correlation between the manager's competencies and the results of the team's work: a good leader can lead a group and achieve ambitious goals. It is not always an easy task, because much depends on the employees, their willingness and commitment to work, and their knowledge and specialist competencies, as well as their personal propensity for teamwork. The employee, seeing that the company fully understands them and, as far as possible, meets their needs, gives much more for the company. They inform leaders about all matters and ask for advice or a defined action. Not surprisingly, then, summarising the analysis of how leaders evaluate the significance of particular areas of managerial staff's work (Kotter's model), we can unequivocally state that, in the opinion of the heads of the largest corporations in the world, the most important activities in their work are, at the same time, the components of leadership functions. This is borne out in both data sets. However controversial as Kotter's views underlying this analysis may seem, it does not change the fact that top management must dynamically develop the skills and character traits they need.

In the context of the energy sector, several key issues should be highlighted. The importance of leadership in the energy sector addresses the transformation of any system, with environmental leadership being particularly key to a company's success. Understanding the characteristics and style of leadership is essential not only for effective company management but also for energy transformation and the transition towards low-carbon technologies. In fact, the important issue is how can this be governed without significant conflict in society and with the greatest benefits for local communities [65]. This mainly concerns the ability to deal with the complexity of environmental issues and mobilise organisations to implement the vision of long-term ecological balance. It also plays a key role in understanding and addressing the expectations of a wide range of actors and profoundly changing organisational practices [66]. Moreover, in the transformation of the energy sector, leaders should build intra-organisational relations to initiate bottom-up-usually emergent and informal-initiatives, including a network of leaders and change agents [67]. In this context, it should be emphasised that effective environmental leadership should inspire effective and efficient initiatives to change the way energy is produced, processed, distributed, used, and managed. The personality of a leader can be the determinant of the success of a project and the role of leadership is to encourage positive relationships, support effective teamwork, raise morale, empower and inspire individuals, and be the driving force behind successful project implementation [68].

\section{Conclusions}

The analysis presented in this paper documents merely a snippet of a dynamically changing world. Due to the ongoing change resulting from turbulence in the environment, this research must be continued in the future. We hope that the understanding of our closest relatives and colleagues, as well as our enthusiasm and determination, will allow us not only to continue but also to further explore the phenomenon of corporate leadership. At the same time, we wish for the analysis conducted in this article to improve the knowledge of the essence and significance of leadership in the global business environment. Cultural diversification, globalisation trends, and the need for creativity, as well as the growing percentage of independent knowledge workers, force leaders to take action to reconcile the need for the individual encouragement and stimulation of employees with building organisational cohesion that will allow the latter to focus on the objectives of the group and the company. Nowadays, when companies are in constant pursuit of more and more ambitious goals, with rapid technological advancements and high expectations of specialist employees, the role of a leader in building the social potential of a company is paramount. A competent leader, while facing a host of obstacles, must be able to create an optimal work environment for employees to fulfil their tasks and for the company to grow. It is therefore crucial for a manager to provide employees with compulsory training opportunities, as well as propose additional training that supports self-education and self-fulfilment. Aided 
by the specialist skills gained in the workplace while spending time learning and gaining experience, the employee identifies with the company and feels valued because they are aware that their knowledge is essential for the company.

The results and conclusions of our study also have certain limitations. The research was conducted among the largest global corporations, hence the conclusions could be applied only to specific geographic regions. The essence of the differences in the development levels or the innovation potential of various countries should be emphasised as well. Some others limitations are the level of business involvement with community participation in specific energy infrastructure projects, sources of knowledge, methods of technology transfer, and the importance of knowledge management in the energy sector. Another aspect is the role of public support in these processes, as well as the degree and scope of cooperation between enterprises and stakeholders, the process of leadership engagement in the transformation of the energy sector, and the level of environmental leadership and its commitment to implementing innovations. The conditions for business created by central and local authorities are extremely important in this aspect. Certainly, pro-innovative support for entrepreneurs in the scope of increasing investments in R\&D activities (e.g., by creating clusters) should be considered positive. This would involve in-depth research involving energy sector actors, including stakeholders, consumers, and the general public. Undoubtedly, the presented research results do not expand upon the issues of the leadership phenomenon. The importance of other leadership characteristics that distinguish companies, such as capital (foreign/domestic) and geographic scope (domestic/international), could be an interesting direction for further research.

Like many notions, such as democracy, love, and beauty, leadership is intuitively understood by most people, but it carries different meanings for each individual. Each attempt to define it illustrates its multi-threaded and ambiguous nature. Future leaders must be smart enough to learn from the experiences of their predecessors, and if today's executives are smart enough to develop new competencies by drawing upon future leaders, then both groups can share leadership skills for the benefit of the organisation. Only such an attitude will enable an evolutionary transformation of leadership to meet the challenges of the future. We cannot help but wonder at future challenges underpinned by even greater changes than what companies face today. In this regard, we can understand and appreciate the huge role that will be played by leaders, who will not only have to swiftly notice and react to emerging opportunities and threats but will also have to build the trust to lead their followers through the turbulent waters of their environment.

Author Contributions: Conceptualisation, R.K. and R.D.; methodology, R.K. and R.D.; software, R.K. and R.D.; validation, R.K. and R.D.; formal analysis, R.K. and R.D.; investigation, R.K. and R.D.; resources, R.K. and R.D.; data curation, R.K. and R.D.; writing-original draft preparation, R.K. and R.D.; writing-review and editing, R.K. and R.D.; visualisation, R.K. and R.D.; supervision, R.K. and R.D.; project administration, R.K. and R.D. All authors have read and agreed to the published version of the manuscript.

Funding: This research received no external funding.

Conflicts of Interest: The authors declare no conflict of interest.

\section{References}

1. Carsten, M.K.; Uhl-Bien, M.; Huang, L. Leader perceptions and motivation as outcomes of followership role orientation and behavior. Leadership 2018, 14, 731-756. [CrossRef]

2. Chen, J.; Silverthorne, C. Leadership effectiveness, leadership style and employee readiness. Leadersh. Organ. Dev. J. 2005, 26, 280-288. [CrossRef]

3. Yukl, G.A. How leaders influence organizational effectiveness. Leadersh. Q. 2008, 19, 708-722. [CrossRef]

4. Karaszewski, R.; Karwacka, M. Skuteczna komunikacja wizji: Recepty światowych liderów. Harv. Bus. Rev. Pol. 2009, 81, 22-24.

5. Zigarmi, D.; Roberts, T.P.; Randolph, W.A. Employees' Perceived Use of Leader Power and Implications for Affect and Work Intentions. Hum. Resour. Dev. Q. 2015, 26, 359-384. [CrossRef]

6. Schnurr, S.; Schroeder, A. A critical reflection of current trends in discourse analytical research on leadership across disciplines. A call for a more engaging dialogue. Leadership 2019, 15, 445-460. [CrossRef] 
7. Landells, E.; Albrecht, S. The Positives and Negatives of Organizational Politics: A Qualitative Study. J. Bus. Psychol. 2017, 32, 41-58. [CrossRef]

8. Wang, H.; Sui, Y.; Luthans, F.; Wang, D.; Wu, A.Y. Impact of authentic leadership on performance: Role of followers' positive psychological capital and relational processes. J. Organ. Behav. 2014, 35, 5-21. [CrossRef]

9. Hersey, P.; Blanchard, K. Situational Leadership in Business Leadership; Jossey-Bass Reader: San Francisco, CA, USA, 2003; pp. 111-116.

10. Harrison, C.; Paul, S.; Burnard, K. Entrepreneurial Leadership: A Systematic Literature Review. Int. Rev. Entrep. 2016, 14, 255-264.

11. Natalicchio, A.; Ardito, L.; Savino, T.; Albino, V. Managing knowledge assets for open innovation: A systematic literature review. J. Knowl. Manag. 2017, 21, 1362-1383. [CrossRef]

12. Oc, B. Contextual leadership: A systematic review of how contextual factors shape leadership and its outcomes. Leadersh. Q. 2018, 29, 218-235. [CrossRef]

13. Parris, D.L.; Peachey, J.W. A Systematic Literature Review of Servant Leadership Theory in Organizational Contexts. J. Bus. Ethics 2013, 113, 377-393. [CrossRef]

14. Yahaya, R.; Ebrahim, F. Leadership styles and organizational commitment: Literature review. J. Manag. Dev. 2016, 35, 190-216. [CrossRef]

15. Northouse, P.G. Leadership: Theory and Practice; Sage: Thousand Oaks, CA, USA, 2003.

16. Hughes, R.L.; Ginnett, R.C.; Curphy, G.J. Leadership: Enhancing the Lessons of Experience; McGraw-Hill: New York, NY, USA, 2006.

17. Avolio, B.; Walumbwa, F.; Weber, T.J. Leadership: Current Theories, Research, and Future Directions. Annu. Rev. Psychol. 2009, 60, 421-449. [CrossRef] [PubMed]

18. Wegge, J.; Shemla, M.; Haslam, S.A. Leader behavior as a determinant of health at work: Specification and evidence of five key pathways. Z. Für Pers. 2014, 28, 6-23. [CrossRef]

19. Cianci, A.M.; Hannah, S.T.; Roberts, R.; Tsakumis, G.T. The effects of authentic leadership on followers' ethical decision-making in the face of temptation: An experimental study. Leadersh. Q. 2014, 5, 581-594. [CrossRef]

20. McDermott, A.; Kidney, R.; Flood, P. Understanding leader development: Learning from leaders. Leadersh. Organ. Dev. J. 2011, 32, 358-378. [CrossRef]

21. Bolden, R. Distributed Leadership in Organizations: A Review of Theory and Research. Int. J. Manag. Rev. 2011, 13, 251-269. [CrossRef]

22. Tourish, D. Leadership, more or less? A processual, communication perspective on the role of agency in leadership theory. Leadership 2014, 10, 79-98. [CrossRef]

23. Wu, W.L.; Lee, Y.C. Empowering group leaders encourages knowledge sharing: Integrating the social exchange theory and positive organizational behavior perspective. J. Knowl. Manag. 2017, 21, 474-491. [CrossRef]

24. Van Seters, D.A.; Field, R.H.G. The evolution of leadership theory. J. Organ. Chang. Manag. 1990, 3, 29-45. [CrossRef]

25. Tung, F.C. Does transformational, ambidextrous, transactional leadership promote employee creativity? Mediating effects of empowerment and promotion focus. Int. J. Manpow. 2016, 37, 1250-1263. [CrossRef]

26. Zareen, M.; Razzaq, K.; Mujtaba, B.G. Impact of Transactional, Transformational and Laisser-Faire Leadership Styles on Motivation: A Quantitative Study of Banking Employees in Pakistan. Public Organ. Rev. 2014, 15, 531-549. [CrossRef]

27. Tichy, N.M.; DeVanna, M.A. The Transformational Leader; Wiley\&Sons: New York, NY, USA, 1996; pp. 271-280.

28. Millar, G. Employee engagement-A new paradigm. Hum. Resour. Manag. Int. Dig. 2012, 20, 3-5. [CrossRef]

29. Tinti, J.A.; Venelli-Costa, L.; Martins, V.A.; Cappellozza, A. The impact of human resources policies and practices on organizational citizenship behaviors. Braz. Bus. Rev. 2017, 14, 636-653. [CrossRef]

30. Reitz, M. Leading questions: Dialogue in organizations: Developing relational leadership. Leadership 2017, 13, 516-522. [CrossRef]

31. Drewniak, R.; Drewniak, Z.; Posadzinska, I. Leadership Styles and Employee Expectations. Eur. Res. Stud. J. 2020, 23, 398-411. [CrossRef]

32. Gandolfi, F.; Stone, S. Clarifying leadership: High-impact leaders in a time of leadership crisis. Rev. Int. Comp. Manag. 2016, 17, 212-224.

33. Crossman, B.; Crossman, J. Conceptualising followership: A review of the literature. Leadership 2011, 7, 481-497. [CrossRef]

34. Ford, J.; Harding, N. The impossibility of the 'true self' of authentic leadership: A critique through object relations theory. Leadership 2011, 7, 463-479. [CrossRef]

35. Bass, B.M. Bass and Stogdill's Handbook of Leadership: A Survey of Theory and Research; Free Press: New York, NY, USA, 1990; pp. 11-21.

36. Kirkeby, O.F. The Virtue of Leadership; Copenhagen Business School Press: Gylling, Denmark, 2008; pp. 171-176.

37. Meschitti, V. The power of positioning: How leadership work unfolds in team interactions. Leadership 2019, 15, 621-643. [CrossRef]

38. Jooste, C.; Fourie, B. The Role of Strategic Leadership in Effective Strategy Implementation: Perceptions of South African Strategic Leaders. S. Afr. Bus. Rev. 2009, 13, 51-68.

39. Hogan, R.T.; Curphy, G.J.; Hogan, J. What do we know about personality: Leadership and effectiveness? Am. Psychol. 1994, 49, 493-504. [CrossRef]

40. Bass, B.M.; Bass, R. The Bass Handbook of Leadership, 4th ed.; Free Press: New York, NY, USA, 2008.

41. Jago, A.G. Leadership: Perspectives in theory and research. Manag. Sci. 1982, 3, 315-336. [CrossRef]

42. Youssef, C.M.; Luthans, F. Positive global leadership. J. World Bus. 2012, 47, 539-547. [CrossRef] 
43. Drath, W.H.; Palus, C.J. Making Common Sense: Leadership as Meaning-Making in a Community of Practice; Center for Creative Leadership: Greensboro, NC, USA, 1994; pp. 4-8.

44. Ehigie, B.O.; Akpan, R.C. Roles of perceived Leadership styles and rewards in the practice of Total Quality Management. Leadersh. Organ. Dev. J. 2004, 25, 24-40. [CrossRef]

45. Cameron, K.S. Positive Leadership: Strategies for Extraordinary Performance; Berett-Koehler Publishers: San Francisco, CA, USA, 2012; pp. 2-4.

46. Walumbwa, F.; Avolio, B.; Gardner, W.; Wernsing, T.; Peterson, S. Authentic leadership: Development and validation of a theory based measure. J. Manag. 2008, 34, 89-126.

47. Posner, B.Z. An investigation into the leadership practices of volunteer leaders. Leadersh. Organ. Dev. J. 2015, 36, 885-898. [CrossRef]

48. Ford, J.; Harding, N. Followers in leadership theory: Fiction, fantasy and illusion. Leadership 2018, 14, 3-24. [CrossRef]

49. Stogdill, R.M. Handbook of Leadership: A Survey of Theory and Research; Free Press: New York, NY, USA, $1974 ;$ p. 7.

50. Fleishman, E.A.; Mumford, M.D.; Zaccaro, S.J.; Levin, K.Y.; Korotkin, A.L.; Hein, M.B. Taxonomic efforts in the description of leader behavior: A synthesis and functional interpretation. Leadersh. Q. 1991, 2, 245-287. [CrossRef]

51. Robertson, I.T.; Birch, A.J.; Cooper, C.L. Job and work attitudes, engagement and employee performance: Where does psychological well-being fit in? Leadersh. Organ. Dev. J. 2012, 33, 224-232. [CrossRef]

52. Drewniak, R. Determinants of Employees' Involvement and the Role of the Leadership Styles in Organisational Commitment: Empirical Findings from Polish Enterprises. Int. J. Contemp. Manag. 2017, 16, 99-125.

53. Shazia, T.S.; Anis-ul-Haq, A.M.; Niazi, G.S.K. Leadership styles: Relationship with conflict management styles. Int. J. Confl. Manag. 2014, 25, 214-225.

54. Fiedler, F.E. A Theory of Leadership Effectiveness; McGraw-Hill: New York, NY, USA, 1967.

55. Adair, J. Developing Leaders: The Ten Key Principles; McGraw-Hill: Maidenhead, UK, 1988; p. 5.

56. Adair, J. Effective Strategic Leadership; Macmillan: London, UK, 2003; pp. 61-86.

57. Xu, L.; Fu, P.; Xi, Y.; Zhang, L.; Zhao, X.; Cao, C.; Liao, Y.; Li, G.; Xue, X.; Ge, J. Adding dynamics to a static theory: How leader traits evolve and how they are expressed. Leadersh. Q. 2014, 25, 1095-1119. [CrossRef]

58. Kinnie, N.; Swart, J. Commitment to whom? Professional knowledge worker commitment in cross-boundary organisations. Hum. Resour. Manag. J. 2012, 1, 21-38. [CrossRef]

59. Stogdill, R.M. Personal factors associated with leadership: A survey of the literature. J. Psychol. 1948, 25, 37-71. [CrossRef]

60. Lord, R.G.; DeVader, C.L.; Alliger, G.M. A Meta-analysis of the relation between personality traits and leadership perceptions: An application of validity generalization procedures. J. Appl. Psychol. 1986, 71, 402-410. [CrossRef]

61. Mann, R.D. A review of the relationships between personality and performance in small groups. Psychol. Bull. 1959, 56, 241-270. [CrossRef]

62. Kirkpatrick, S.; Locke, E. Direct and indirect effects of three core charismatic leadership components on performance and attitudes. J. Appl. Psychol. 1996, 81, 36-51. [CrossRef]

63. Kouzes, J.; Posner, B. The Leadership Challenge, 6th ed.; Jossey-Bass: San Francisco, CA, USA, 1988.

64. Kotter, J.P. A Force for Change: How Leadership Differs from Management; Free Press: New York, NY, USA, 1990.

65. Xavier, R.; Komendantova, N.; Jarbandhan, V.; Nel, D. Participatory governance in the transformation of the South African energy sector: Critical success factors for environmental leadership. J. Clean. Prod. 2017, 154, 621-632. [CrossRef]

66. Borial, O. Corporate Greening through ISO 14001: A Rational Myth? Organ. Sci. 2007, 18, 127-146. [CrossRef]

67. Taylor, A. The Role of Leadership for Environment and Sustainability. Guest Lecture: Perspectives on Environment and Sustainability; Monash University: Melbourne, Australia, 2011.

68. Kemei, D.; Oboko, R.; Kidombo, H. The influence of top management support on the relationship between project manager leadership competencies and ERP system project performance: Findings from Kenya energy sector. Int. Acad. J. Innov. Leadersh. Entrep. 2018, 2, 195-210. 